\title{
Caddo Ceramic Assemblage from a Site Across the Road from the Millsey Williamson Site in Rusk County, Texas
}

Timothy K. Perttula

Heritage Research Center, Stephen F. Austin State University

Follow this and additional works at: https://scholarworks.sfasu.edu/ita

Part of the American Material Culture Commons, Archaeological Anthropology Commons, Environmental Studies Commons, Other American Studies Commons, Other Arts and Humanities Commons, Other History of Art, Architecture, and Archaeology Commons, and the United States History Commons

Tell us how this article helped you.

This Article is brought to you for free and open access by the Center for Regional Heritage Research at SFA ScholarWorks. It has been accepted for inclusion in Index of Texas Archaeology: Open Access Gray Literature from the Lone Star State by an authorized editor of SFA ScholarWorks. For more information, please contact cdsscholarworks@sfasu.edu. 


\section{Caddo Ceramic Assemblage from a Site Across the Road from the Millsey Williamson Site in Rusk County, Texas}

\section{Creative Commons License}

\section{(c) (1) (8)}

This work is licensed under a Creative Commons Attribution-NonCommercial 4.0 International License 


\title{
Caddo Ceramic Assemblage from a Site Across the Road from the Millsey Williamson Site in Rusk County, Texas
}

\author{
Timothy K. Perttula
}

\section{INTRODUCTION}

In archaeological investigations by Jones (1968:62-84 and Figure 5) at the Nadaco Caddo Millsey Williamson site (41RK3), he identified a burial area on the western tip of an alluvial terrace landform on the east side of Martin Creek, as well as a village area to the east (Figure 1). The burial area and the village area were separated by a road, a paved segment of the $19^{\text {th }}$ century Trammel's Trace (see Snowden 2015). Trammel's Trace was an Anglo-American version of the aboriginal Caddo Trace "that led from the Hasinai Caddo settlements in East Texas to the Kadohadacho settlements on the Red River in the general area of Texarkana, Texas, and its route is fairly well known because the historic $19^{\text {th }}$-century Trammel's Trace followed its route through northeastern Texas" (Perttula et al. 2010:5). The collection of ceramic sherds discussed in this article are from the village, namely the site area across [and to the east] from the Millsey Williamson historic Caddo cemetery; they are in the collections of the Gregg County Historical Museum. A number of the sherds were collected from this area before 1945 by a Mr. C. W. Bailey, who donated them to Buddy Jones for study.

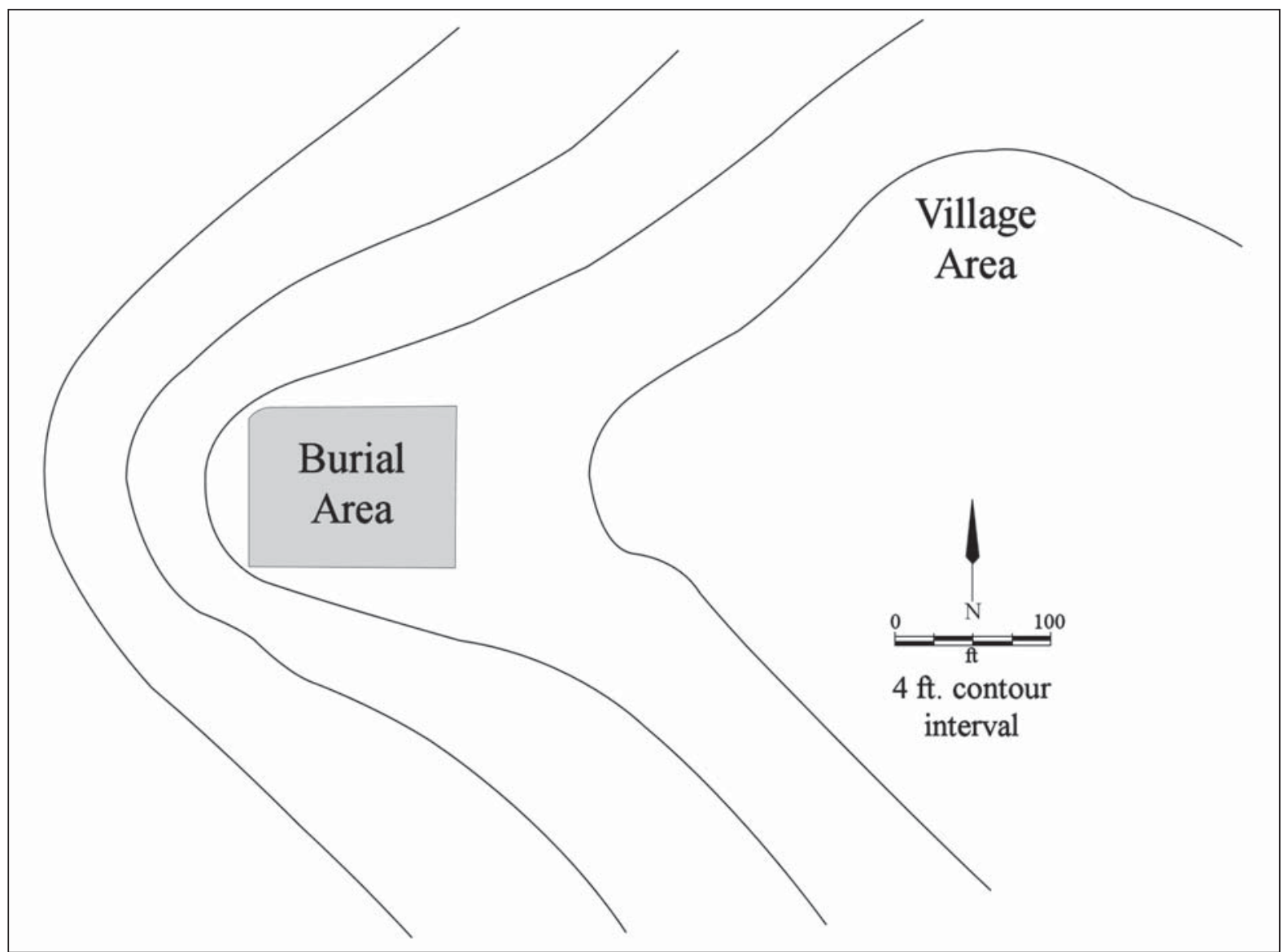

Figure 1. Map of the Millsey Williamson site (41RK3), showing the burial area to the west and the village area to the east. 


\section{Ceramic Sherd Assemblage}

The ceramic assemblage from the Millsey Williamson village area has sherds from plain ware, utility ware, and fine ware vessels. More than 90 percent of the sherds are from grog-tempered vessels (Table 1). The plain to decorated sherd ratio of this assemblage is 1.62 , and utility ware rim and body sherds represent about 88 percent of the decorated sherd total.

Table 1. Ceramic sherd assemblage from the village area east of the burial area at the Millsey Williamson site.

\begin{tabular}{lccc}
\hline Ware & Grog-tempered & Bone-tempered & $\mathrm{N}$ \\
\hline Plain & 203 & 31 & 234 \\
Utility & 123 & 2 & 125 \\
Fine & 15 & 3 & 18 \\
\hline Totals & 341 & 36 & 377 \\
\hline
\end{tabular}

The utility wares from the Millsey Williamson village are stylistically diverse, with jars being decorated on the rim and/or vessel body with appliqued, appliqued-incised, appliqued-punctated, brushed, brushedappliqued-incised, incised, incised-punctated, pinched, and punctated decorative elements (Table 2). Sherds from vessels decorated with incised lines are by far the most commonly represented in the assemblage, including 64 percent of the rims and 58 percent of all the sherds. Other significant decorative methods represented in the utility wares are brushing (10.5 percent), and incised-punctated (11.2 percent). Sherds with appliqued elements - either as the sole decorative element or in combination with incised, punctated, and brushed-incised elements - comprise 5.6 percent of all the decorated sherds from this part of the site.

Table 2. Decorative methods and elements in the utility ware sherds from the village area east of the burial area at the Millsey Williamson site.

\begin{tabular}{|c|c|c|c|}
\hline $\begin{array}{l}\text { Decorative method/ } \\
\text { Decorative element }\end{array}$ & Rim & Body & $\mathrm{N}$ \\
\hline \multicolumn{4}{|l|}{ Appliqued } \\
\hline straight appliqued fillet & - & 3 & 3 \\
\hline \multicolumn{4}{|l|}{ Appliqued-Incised } \\
\hline straight appliqued fillet and diagonal incised lines & - & 2 & 2 \\
\hline straight appliqued ridge and parallel incised lines & - & 1 & 1 \\
\hline \multicolumn{4}{|l|}{ Appliqued-Punctated } \\
\hline $\begin{array}{l}\text { straight appliqued fillet and adjacent tool } \\
\text { punctated row }\end{array}$ & - & 1 & 1 \\
\hline \multicolumn{4}{|l|}{ Brushed } \\
\hline parallel brushing marks & - & 15 & 15 \\
\hline \multicolumn{4}{|l|}{ Brushed-Appliqued-Incised } \\
\hline $\begin{array}{l}\text { straight appliqued fillet, curvilinear brushing } \\
\text { marks, and diagonal incised lines }\end{array}$ & - & 1 & 1 \\
\hline \multicolumn{4}{|l|}{ Incised } \\
\hline broad, straight line & - & 5 & 5 \\
\hline
\end{tabular}


Table 2. Decorative methods and elements in the utility ware sherds from the village area east of the burial area at the Millsey Williamson site.

\begin{tabular}{|c|c|c|c|}
\hline $\begin{array}{l}\text { Decorative method/ } \\
\text { Decorative element }\end{array}$ & $\operatorname{Rim}$ & Body & $\mathrm{N}$ \\
\hline cross-hatched lines & - & 2 & 2 \\
\hline curvilinear lines & - & 1 & 1 \\
\hline diagonal lines & 5 & 3 & 8 \\
\hline diagonal opposed lines & - & 4 & 4 \\
\hline horizontal lines & $3 *$ & - & 3 \\
\hline horizontal, diagonal, and cross-hatched lines & 1 & - & 1 \\
\hline parallel lines & - & 48 & 48 \\
\hline straight line & - & 6 & 6 \\
\hline vertical and diagonal opposed lines & - & 5 & 5 \\
\hline \multicolumn{4}{|l|}{ Incised-Punctated } \\
\hline $\begin{array}{l}\text { curvilinear incised row filled with tool } \\
\text { punctations }\end{array}$ & - & 1 & 1 \\
\hline $\begin{array}{l}\text { diagonal opposed triangles filled with tool } \\
\text { punctations }\end{array}$ & 3 & 1 & 4 \\
\hline diagonal opposed lines and tool punctated row & - & 1 & 1 \\
\hline $\begin{array}{l}\text { horizontal lines, tool punctated row, and vertical } \\
\text { panel filled with diagonal lines }\end{array}$ & - & 1 & 1 \\
\hline $\begin{array}{l}\text { horizontal incised panels filled with tool } \\
\text { punctations }\end{array}$ & 1 & 1 & 2 \\
\hline straight line and adjacent tool punctated zone & - & 5 & 5 \\
\hline $\begin{array}{l}\text { vertical and diagonal lines and diagonal-filled } \\
\text { tool punctated zone }\end{array}$ & - & 2 & 2 \\
\hline \multicolumn{4}{|l|}{ Pinched } \\
\hline straight pinched ridge & - & 1 & 1 \\
\hline \multicolumn{4}{|l|}{ Punctated } \\
\hline fingernail punctated rows & - & 1 & 1 \\
\hline tool punctated rows & - & 1 & 1 \\
\hline Totals & 13 & 112 & 125 \\
\hline
\end{tabular}

*one rim is lip notched

The appliqued sherds have decorative elements that suggest the appliqued element was used to divide the vessel body of Pease Brushed-Incised or Reavely Brushed-Incised jars into vertical panels filled with other decorative elements, including diagonal incised lines (Figure 2a) and diagonal incised lines and curvilinear brushing marks (Figure $2 \mathrm{~b}$ ). The brushed sherds in the assemblage are from the body of Bullard Brushed vessels, and the brushing was likely oriented vertically on the vessel.

The incised rim sherds have diagonal, horizontal, and horizontal-diagonal-and cross-hatched zones (see Figure 2c and Table 2). These sherds are likely from both Maydelle Incised and Pease Brushed-Incised jars; one of the horizontal incised rims has lip notching. A number of the incised body sherds are also from Pease Brushed-Incised vessels: they have vertical lines defining panels filled with diagonal opposed incised lines (see Suhm and Jelks 1962:Plate 60k). 


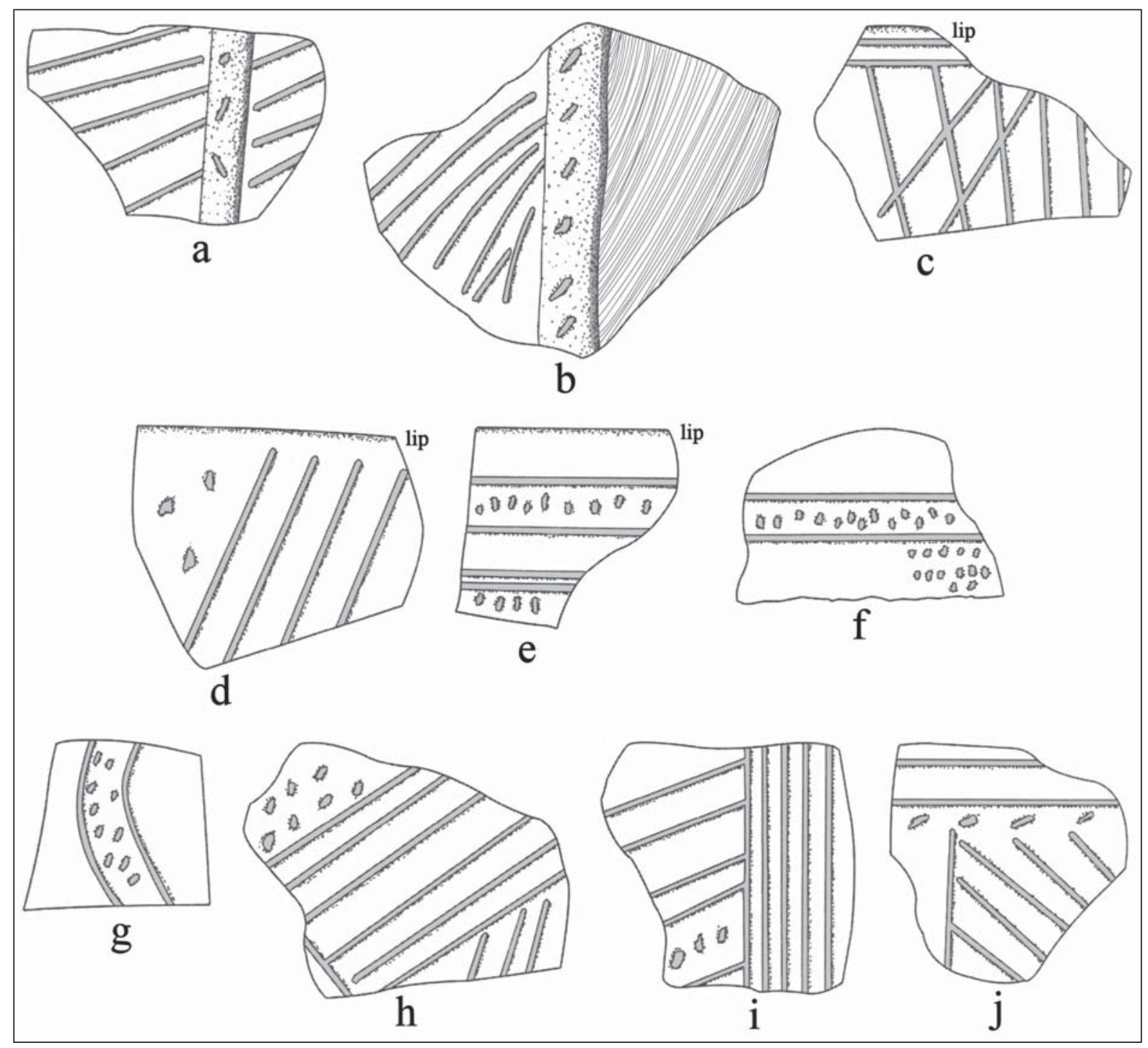

Figure 2. Selected decorative elements on utility ware sherds from the village area at the Millsey Williamson site: a, appliqued-incised body sherd; b, appliqued-brushed-incised body sherd; c, incised rim sherd; d-i, incised-punctated rim and body sherds.

Three of the incised-punctated rim sherds and one body sherd are from Maydelle Incised jars that have diagonal opposed incised triangles that are filled with tool punctations (see Figure 2d). Other incisedpunctated rim and body sherds have narrow horizontal incised panels filled with tool punctations (see Figure 2e-f), and one other body sherd has a narrow curvilinear incised panels filled with tool punctations (see Figure $2 \mathrm{~g}$ ). Other body sherds have more complex incised-punctated elements featuring diagonal opposed incised lines and tool punctated-filled triangular zones (see Figure 2h), vertical and diagonal incised lines and a diagonal incised panel filled with punctations (see Figure 2i), and a horizontal incised lower rim, a row of tool punctations at the rim-body juncture, and a vertical incised panel filled with diagonal incised lines (see Figure 2j). Such incised-punctated decorative elements are present in the Oak Hill Village (41RK214) utility ware sherd assemblage (Rogers and Perttula 2004:226-232) as well as the ca. A.D. 1340-1450 ceramic assemblage at the Musgano site (41RK19) on Martin Creek (Perttula 2014:16-20).

The one body sherd with a straight pinched ridge may be from a Killough Pinched vessel (see Suhm and Jelks 1962:Plate 46). The punctated body sherds have rows of either fingernail or tool punctations (see Table 2). 
The fine ware sherds are from engraved or red-slipped vessels (Table 3); the one red-slipped sherd represents 0.7 percent of the decorated sherd assemblage from the village area ceramic sherd sample from the Millsey Williamson site. The engraved and red-slipped sherds are from bowls and carinated bowls, except for one engraved bottle body sherd. The one engraved rim sherd has vertical engraved lines.

Table 3. Decorative methods and elements in the fine ware sherds from the village area east of the burial area at the Millsey Williamson site.

\begin{tabular}{|c|c|c|c|}
\hline $\begin{array}{l}\text { Decorative method/ } \\
\text { Decorative element }\end{array}$ & Rim & Body & $\mathrm{N}$ \\
\hline \multicolumn{4}{|l|}{ Engraved } \\
\hline cross-hatched triangular zone & - & 2 & 2 \\
\hline horizontal lines & - & 2 & 2 \\
\hline horizontal and curvilinear lines & - & 1 & 1 \\
\hline horizontal-diagonal lines & - & 1 & 1 \\
\hline parallel lines & - & 3 & 3 \\
\hline scroll element & - & 1 & 1 \\
\hline engraved snake element* & - & 1 & 1 \\
\hline straight line & - & 2 & 2 \\
\hline straight and curvilinear lines & - & 1 & 1 \\
\hline straight line and small excised tick marks & - & 2 & 2 \\
\hline vertical lines & 1 & - & 1 \\
\hline \multicolumn{4}{|l|}{ Red-Slipped } \\
\hline ext. red-slipped & - & 1 & 1 \\
\hline Totals & 1 & 17 & 18 \\
\hline
\end{tabular}

*bottle

The most distinctive of the engraved sherds is the one bottle sherd in this assemblage that has part of an cross-hatched engraved rattlesnake motif (Figure 3a). Engraved canebrake rattlesnake motifs on bottles have been found in ceramic assemblages in at least 17 Middle Caddo and Late Caddo period sites in the Big and Little Cypress Creek, mid-Sabine, Red River, and Angelina River basins in East Texas (Walters 2006; Gadus 2013:221). The motif consists of "representational images of snakes with entwined or interlocking tails" (Gadus 2013:221). At the Millsey Williamson site, the bottle sherd has a cross-hatched zone that may represent part of the body of the snake.

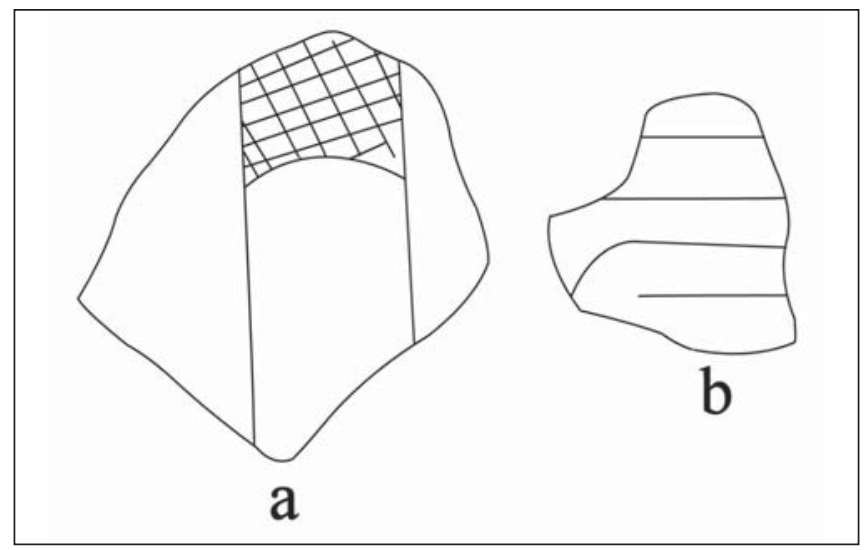

Figure 3. Selected engraved decorative elements on body sherds in the village area at the Millsey Williamson site: a, engraved bottle sherd; $b$, engraved carinated bowl sherd. 
Other engraved body sherds have cross-hatched triangular engraved zones, which are common decorative elements in the Musgano site ceramic assemblage (Perttula 2014:Table 11), as well as one sherd with horizontal and curvilinear lines that are likely part of a horizontal scroll element (see Figure 3b), and a second body sherd with part of a horizontal-slanting scroll element. Two body sherds have a straight line that ends in a small excised tick mark.

\section{SUMMARY AND CONCLUSIONS}

Buddy Calvin Jones, and Mr. C. W. Bailey before him, collected a sample of plain and decorated Caddo ceramic vessel sherds from a village area east of the cemetery at the Millsey Williamson site (41RK3) on Martin Creek. This collection of 377 ceramic vessel sherds, now in the holdings of the Gregg County Historical Museum, is primarily from grog-tempered vessels, including plain ware, many utility ware sherds, and fine ware sherds.

The utility ware sherds are dominated by sherds from incised vessels, including Maydelle Incised jars, and Bullard Brushed and Pease Brushed-Incised vessel sherds are also present in the assemblage. Engraved and red-slipped sherds are not common in this ceramic assemblage (12.6 percent of the decorated sherd assemblage). The most distinctive of the engraved sherds from this part of the Millsey Williamson site is a bottle sherd with an engraved rattlesnake motif. In the local area, sherds with this motif have been found at the Oak Hill Village (41RK214) (Rogers and Perttula 2004:Figures 91p and 92), 41RK242 (Perttula 2001), Musgano (41RK19, Perttula 2014), and 41HS74 (Heartfield, Price, and Greene, Inc. 1988:Figure 6-16). These sites have ancestral Caddo components that range from ca. A.D. 1150-1450 in age (Perttula 2014:Table 13). The occurrence of the engraved rattlesnake sherd and the relatively low proportions of brushed sherds in the assemblage (11.2 percent) suggests that this assemblage of sherds from the Millsey Williamson site is contemporaneous with Group II ceramic assemblages in the middle Sabine River basin (see Rogers and Perttula 2004:Table 68), namely from the mid $-13^{\text {th }}$ to the mid-14 ${ }^{\text {th }}$ century A.D., during the Middle Caddo period. No decorated ceramic sherds from the Historic Nadaco Caddo occupation of the Millsey Williamson site (see Jones 1968; Perttula and Nelson 2007, 2014) are represented in this collection from the village area east of the burial area at the site.

\section{ACKNOWLEDGMENTS}

Patti Haskins of the Gregg County Historical Museum facilitated the study of this ceramic sherd assemblage. Lance Trask prepared the figures in this article. 


\section{REFERENCES CITED}

Gadus, E. F.

2013 Twisted Serpents and Fierce Birds: Structural Variation in Caddo Engraved Ceramic Bottle Motifs. Bulletin of the Texas Archeological Society 84:213-245.

Heartfield, Price, and Greene, Inc.

1988 Data Recovery at 41HS74, Harrison County, Texas. Heartfield, Price, and Greene, Inc., Monroe.

Jones, B. C.

1968 The Kinsloe Focus: A Study of Seven Historic Caddoan Sites in Northeast Texas. Master's thesis, Department of Anthropology, University of Oklahoma, Norman.

Perttula, T. K.

2001 Ceramic Analysis. In NRHP Eligibility Testing (41RK107, 41RK240, 41RK242, 41RK243, 41RK276, and 4IRK286) and Additional Testing (41RK243) Investigations within the Oak Hill DIII Mine, Permit No. 46, Rusk County, Texas, by D. L. Sherman. Document No. 000237. PBS\&J, Austin.

2014 The Caddo Archaeology of the Musgano Site (41RK19) in the Sabine River Basin of East Texas. Special Publication No. 28. Friends of Northeast Texas Archaeology, Pittsburg and Austin.

Perttula, T. K. and B. Nelson

2007 Documentation of a Collection of Archaeological Materials from the Millsey Williamson Site (41RK3), A Historic Nadaco Caddo Settlement. Journal of Northeast Texas Archaeology 26:120-127.

2014 The Millsey Williamson (41RK3), Bead Burial, and L. N. Morwell Farm Sites on Martin Creek: Historic Caddo Settlements along Trammels Trace, Rusk County, Texas. Journal of Northeast Texas Archaeology 44:23-46.

Perttula, T. K., B. Nelson, R. L. Cast, and B. Gonzalez

2010 The Clements Site (41CS25): A Late 17th to Early 18th-Century Nasoni Caddo Settlement and Cemetery. Anthropological Papers No. 92. American Museum of Natural History, New York.

Rogers, R. and T. K. Perttula

2004 The Oak Hill Village (41RK214), Rusk County, Texas. Document No. 030083. PBS\&J, Austin.

Snowden, K. A.

2015 Trammel's Trace on Printed Maps of the 19th Century. CRHR Research Reports: Volume 1, Article 2. http://scholarworks.sfasu.edu/crhr_research_reports/vol1/iss $1 / 2$

Suhm, D. A. and E. B. Jelks (editors)

1962 Handbook of Texas Archeology: Type Descriptions. Special Publication No. 1, Texas Archeological Society, and Bulletin No. 4, Texas Memorial Museum, Austin. Reprinted in 2009, Gustav's Library, Davenport, Iowa.

Walters, $\mathrm{M}$.

2006 The Lake Clear (41SM243) Site and Crotalus horridus atricaudatus. Caddoan Archeology Journal 15:5-41. 